\title{
The Use of Modern Technologies in the Follow up of Cadet's Formation in Football Schools
}

\begin{abstract}
We cannot deny that formation academies and schools of football are the responsible one for creating a generation of sport talents which support national teams and clubs.

Recently, most countries were interested in making plans to develop team's age stages through building up formation schools so as to realize a self - sufficiency in high level teams. In this intervention we will make an analytical study in which we concentrate on the importance of the use of modern technology in training and its role in the success of these schools. This is through the follow up of formation related to the preparation of modern training programs which are science - based. Indeed, these programs are conditioned with various age stages and the selection of specialized trainers in a scientific method. Because they know the characteristics of each age stage based on morphological, physiological, physical, skillful, psychological factors and of course through the use of technological means that give exact results in comparison with traditional methods, in order to form players according to scientific methods.
\end{abstract}

\section{Ahmed Hamza GHADBANE Fathi BELGHOUL \\ Tahar BRIKI \\ Nabil KERFES}

Laboratory of Sciences and Techniques of Physical and Sport Activities University of Algiers 3

(Algeria)

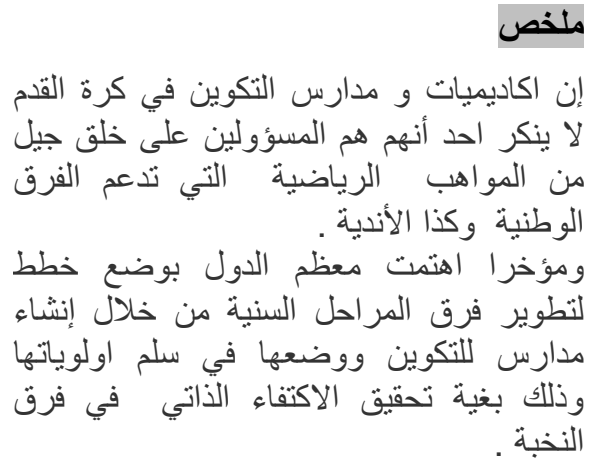

\section{Introduction}

The developed countries in the field of sport make an effort to prepare cadet footballers based on clear scientific ways. The studies which analyzed performance during Olympics and international tournaments showed that realizing advanced results is for those who havekinetic talent, a high physical efficiency, a high degree skill, and a strong will. All these factors are important in selecting cadets and preparing them, in the long and short term.

Footballers' selection was and still in different places in the world based on personal experience and choosing the players who shows some skills or kinesthetic performance of the game without using any objective measures that ensures the progress 
ومن خلال ذلك نقوم بدراسة تحليلية نركز فيها

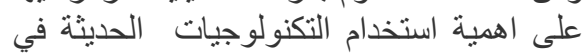

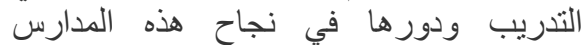
الكروية من خلال متابعة التكوين المتعلق بإعداد فلداد

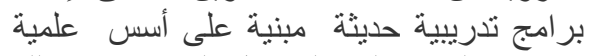

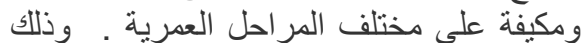
باعتمادها على ركائز أساسية متمنلة في انتقاء

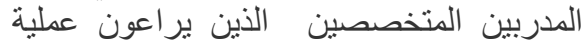

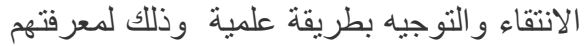

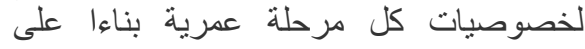

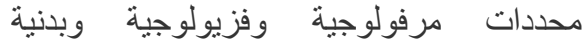

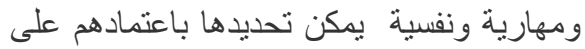
الوسائل التكنولوجية الحديثة التي تعطي نتئية نائج دقيقة مقارنة بطرق القياس التقليدية. ورالنتائج المتحصل عليها تسمح بالمتابعة العلمية لمختلف

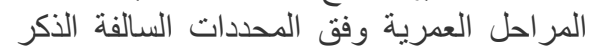

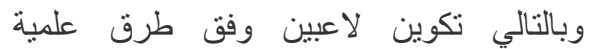
مدروسة.وكل هذه الاستر اتيجيات العلمية سوف طاعن نفصلها في هذا المقال. of the cadet. It is proved that this method "personal experience" which is use by $70 \%$ of trainers leads to many mistakes; also preparing cadet to reach a high-level needs a long period of preparation. According to many researches, the effectiveness of selection will increase if it is done through the different stages of long term preparation.

Formation Schools and Its Requirement International formation schools of football depend on scientific bases in the selection and the orientation of players, relying on field specialists who realize the requirement of the youth category. Those specialists should meet the necessary conditions for the rehabilitation of those players. The most important condition for those specialists is the scientific certificate that concentrates in its content on the characteristics of age categories, individual differences, determinants of selection and orientation (physical, morphological, physiological, and psychological). During selection we need to consider all of them together.

\section{Age Category Appropriate for the Selection}

Determining the appropriate age to choose talents is an important process. Opinions about this determination were varied because each sport activity needs a different age from the other activities. So they decide to consider two essential factors in determining the appropriate age. First, to determine cadet's age for each activity (it is the time period to reach a best level of kinetic capabilities and biological bases), and to determine the number of the training years to ensure the rehabilitation of the player. Second, to know the appropriate level of physical standards and abilities to withstand the requirements of training. Throughout these two factors we can determine the appropriate age of selection.

This does not mean that cadets start the practice of sport activity from this age, instead they need to start before and since childhood. The process of selection starts based on the level on the activity in general, after a period they may be oriented to different activities according to their readiness,desire and a training program. For example, in football, during this period we may know the path of capacities' development on the light of the applied program. In general, selection may depend on the level of football capacities, the speed of learning, the speed of development and level's stability. 
The specialists in football training agreed that the early age of detection starts from(10 to 12 years), the age of specialization starts from (11 to 13 years), and the age of tournaments from (16 to 18 years). It is an ongoing process through serial stages starts by selection stage, then the specialization selection, after that the final selection. In each stage we need to take in consideration the biological age as well as the chronological age.

One of the problems that hurdle the process of selection is the synchronization between the selection period and the highly varied stages of adolescents' period. This problem postpones the possibility of future success predictions because normally cadets realize best levels in football between (17 and 25 years) and this period of time is unstable. That's why specialists didn't rely on the results of the first stage of selection. It is predicted that test's results appears after a year and a half from the beginning training and selection.

\section{The Importance of Modern Technology in Training}

So that coaches can control the determinants in an exact scientific way, they need to be able to use the modern technology. It is through the use of this technology for each element of physical fitness's elements to develop it in a scientifically studied way;For example, to use modern tools of video analysisor to use psychological test and measurements. Many modern scientific studies show that the use of modern technologies lead to an access of exact results and therefore to respect training principles according to scientific standards that lead to the increase in the level of athletes and the formation of good cadets.

\section{Conclusion}

All in all, we can deduce the important role of modern technologies in sport. It is necessary for the success of the scientific training programs used in formation schools based on specialists in the field who control the use of these technologies. 


\section{References}

- Order number 95-09 dated in Ramadan in 1415, in 25 February 1995.Directing the National System of Physical and Sport Education, Organizing and Developing it, Ministry of Youth and Sports,

- ImenElsamrai and AmerKandildji, Quantitative and Qualitative Scientific Research, Dar Elyazouri, Jordan, 2009.

- Zidane NadjibHouachine, Teaching Talented Children, $2^{\text {nd }}$ edition, Dar Elfikr, Aman, 1998.

- Zineb Mohamed Chakir, Promoting the Talented, the Excellent and the Gifted, Elnahda Library, 1998.

- Samia Moussa, School Role in Promoting the Excelent, Projects, Studies and Conferences for Promoting the Excelent, Ministry of Education, Egypt, 1991.

- Said Hosni Elaza, Breeding the Talented and the Excelent, Dar Elsafa, $\quad 1^{\text {st }}$ Edition, Aman, 2000.

- MohamedHazim, Mohamed Abou Yousef, Foundations' Choice of Cadets in Football, Dar Elwafa, Iskandaria, $1^{\text {st }}$ Edition, 2005.

- Mohamed LotfiTaha, The Scientific Basis for the Selection of Athletes, Elamiria Printing House, Kairo, 2001.

- Moufti Ibrahim Hamad, Physical Training from Childhood to Adolescence, $1^{\text {st }}$ Edition, Dar Elfikr, Kairo, 1996. 